\title{
Botulinum neurotoxin-A treatment of lower urinary tract symptoms in multiple sclerosis
}

\author{
Oussama El Yazami Adli, MD; Jacques Corcos, MD, FRCSC
}

Department of Urology, Jewish General Hospital, McGill University, Montreal, QC

Cite as: Can Urol Assoc J 2014;8(1-2):e61-7. http://dx.doi.org/10.5489/cuaj.1824

Published online January 14, 2014.

\section{Abstract}

Multiple sclerosis (MS) is the most common neuroinflammatory disease of the central nervous system and a leading cause of disability in young adults. Symptoms related to vesicourethral dysfunction are very prevalent, but not specific to underlying urodynamic abnormalities. Detrusor overactivity and detrusor external sphincter dysynergia are the most frequent findings and are usually linked. Botulinum neurotoxin-A injection represents a significant advance in the management of voiding dysfunction among MS patients failing first-line therapy. It significantly improves patients' urodynamic parameters and quality of life, with efficacy sustained by repeated injections and minimal risk of adverse events.

\section{Introduction}

Multiple sclerosis (MS) is the most common neuroinflammatory disease of the central nervous system (CNS). It typically occurs between the ages of 29 and 40, and its prevalence depends on geographic location; southern Canada and the United States are high-incidence areas (more than 100 per 100000 population). ${ }^{1} \mathrm{MS}$ is the leading cause of disability in young adults. Its socioeconomic consequences and impact on patients' quality of life (QoL) are considerable. ${ }^{2}$

MS displays marked clinical heterogeneity and can progress through different modes. Diagnosis meets the revised McDonald criteria with magnetic resonance imaging (MRI) and timing intervals. ${ }^{3}$ Bladder and urethral dysfunction develops within 6 to 10 years after disease onset and is reported in $50 \%$ to $96 \%$ of patients, coinciding with disease progression and symptom severity.4-6 Urinary symptoms are not specific to underlying urodynamic abnormalities. In addition, the evolution of MS results in increasing disability and damage at multiple CNS levels, modifying symptoms and urodynamic findings over time with later treatment failure.

Botulinum neurotoxin-A (BONT-A), and specifically onabotulinumtoxinA, is currently approved by the US Food and Drug Administration and by many European countries for the management of voiding dysfunction in MS patients. Its injection results in the significant improvement of urodynamic and QoL parameters.

\section{Pathophysiology of lower urinary tract symptoms in MS}

The normal process of bladder storage and voiding involves complex networks with activation or inhibition of the pontine micturition centre (PMC). Pathways from the PMC project to different levels of the spinal cord, rather than to the bladder and external urethral sphincter (EUS), via multiple peripheral nerves and elicit different reflexes. ${ }^{7-9}$ Lesions affecting the connection of the PMC and spinal centres culminate in a lack of EUS inhibition at the time of micturition (detrusor external sphincter dysynergia [DESD]), and in the emergence of segmental reflexes responsible for uncontrolled detrusor contractions in response to bladder distension (detrusor overactivity [DO]). Detrusor areflexia and reduction of bladder sensation may occur as well. ${ }^{10}$ Different combinations of detrusor and EUS-related symptoms can be seen.

These conditions tend to worsen as the disease progresses, either in relapsing/remitting or progressive mode, primarily in relation to increased spinal cord involvement. ${ }^{11,12}$ Worsening paraparesis and spasticity (evaluated by the Expanded Disability Status Scale [EDSS]), reduction of general mobility, recurrent urinary tract infections (UTI) and cognitive impairment are responsible for worsening symptoms as well. ${ }^{13,14}$

Some authors postulate correlations between urological complaints, urodynamic studies (UDS) and spinal cord abnormalities on MRI, ${ }^{15,16}$ but others have not established significant connections between CNS levels and voiding 
dysfunction ${ }^{17,18}$ in imaging and autopsy studies. Few have reported associations of urinary symptoms with brain MRI parameters. ${ }^{19}$

\section{Evaluation and management of LUT symptoms in MS patients}

Lower urinary tract symptoms (LUTS) are polymorphic and subject to changes, depending on the clinical evolution of MS (Table 1). Motor handicap severity is regularly correlated with the incidence of voiding dysfunction. ${ }^{11,12}$

The most prevalent symptoms are frequency, urgency and urinary urge incontinence (UUI) $(32 \%-99 \%, 32 \%-85 \%$ and $19 \%-80 \%$, respectively). Obstructive symptoms are found, but to a lesser degree. The clinical presentation of vesicourethral dysfunction (VUD) offers little information on the type and severity of detrusor-sphincter disorders, and is highly influenced by MS duration, as well as neurological deficiencies and disabilities (estimated through the EDSS). ${ }^{25}$ Also, men are more prone to developing obstructive symptoms, whereas women experience incontinence and irritative symptoms.

UDS are essential to evaluate MS patients for appropriate first-line management and in cases of therapeutic failure, new urinary symptoms or when surgical or intravesical treatment is planned. Of note, half of "asymptomatic" MS patients present UDS abnormalities and almost $30 \%$ of patients experiencing LUTS do not show UDS aberrations. ${ }^{26}$ DO is the most frequent finding (34\%-90\%): first overactive contraction amplitude, maximum detrusor pressure and threshold bladder volume are reported to be higher among MS patients compared to neurogenic and idiopathic DO. ${ }^{27}$ Detrusor underactivity (DU) (5\%-37\%) and poor bladder compliance ( $2 \%-10 \%)$ are also encountered..$^{25}$ These findings change unpredictably over time in more than $50 \%$ of patients, independently of clinical neurological stability. ${ }^{28}$ DESD occurs in $6 \%$ to $82 \%$ of cases, in association with either DO or DU, and it usually persists once DO or DU has developed. ${ }^{26}$

Urological complications in MS include those in the lower urinary tract (UTI, bladder alteration) and upper urinary tract (renal calculi, hydronephrosis, vesicoureteral reflux and renal insufficiency). These complications seem to be less common in MS compared to spinal cord injury (SCl) patients, with no reason identified. ${ }^{29}$ The duration of disease progression, method of urinary drainage and postvoid residual (PVR) are the principal risk factors for urological complications. DESD, male gender and age over 50 years are also considered risk factors. ${ }^{25}$

Management (i.e., initial rehabilitation and behavioural techniques [fluid intake, bladder emptying]) should account for patients' mental status and disabilities. Reflex voiding is potentially dangerous and should be replaced by clean intermittent catheterization $(\mathrm{CIC})$ in patients with DU or DESD and significant PVR. CIC is superior to both indwelling and suprapubic catheters in reducing UTI. Antimuscarinics, especially long-acting formulations, seem to be logical first-line treatments, as most symptoms are related to DO. However, the evidence for their administration is poor, and the progressive nature of the disease with shifting urodynamic consequences, along with increased rates of adverse events, limits their prescription. ${ }^{30,31}$ Alpha-adrenergic antagonists may reduce outlet resistance, and other oral therapies (desmopressin and cannabinoids) may be indicated to improve urinary symptoms in specific situations. ${ }^{29,32}$ Intravesical therapy of urgency and incontinence with vanilloid agents (resiniferatoxin, capsaicin) has delivered inconsistent outcomes. ${ }^{33}$ Sacral nerve stimulation appears to be more effective than posterior tibial or dorsal penile/clitoral stimulation; however, the implantable stimulator precludes further MRI evaluation. ${ }^{34}$ Surgical interventions (urethral sphincterotomy, urinary diversion/reconstruction) can be offered to select patients with careful preoperative counselling.

\section{BONT-A in MS}

\section{Rationale of treatment, dosage, concentration and injection technique}

BONT-A is synthesized by Clostridium botulinum strains. Its effect in treating VUD in MS is attributed to temporary and reversible paralysis of the injected detrusor or EUS by blocking the vesicular release of parasympathetic acetylcholine

\begin{tabular}{|c|c|c|c|c|c|c|}
\hline Authors & No. patients & Urgency & UUI & Frequency & Dysuria & Urinary retention \\
\hline Awad et al. ${ }^{11}$ & 47 & $85.1 \%$ & $72.3 \%$ & $65 \%$ & $36.1 \%$ & - \\
\hline Mayo and Chetner ${ }^{20}$ & 89 & $71 \%$ & $57 \%$ & $57 \%$ & $56 \%$ & - \\
\hline Amarenco et al. ${ }^{21}$ & 225 & $72 \%$ & $63 \%$ & $42 \%$ & $46 \%$ & $24 \%$ \\
\hline Koldewijn et al. ${ }^{12}$ & 211 & $38 \%$ & $26 \%$ & $38 \%$ & $27 \%$ & - \\
\hline Giannantoni et al. ${ }^{22}$ & 116 & - & $41.7 \%$ & $99 \%$ & $79.5 \%$ & - \\
\hline Gallien et al. ${ }^{23}$ & 149 & $79.8 \%$ & $69.1 \%$ & $67.7 \%$ & $73.8 \%$ & - \\
\hline Hennessey et al. ${ }^{24}$ & 191 & $71 \%$ & $58 \%$ & $76 \%$ & $48 \%$ & - \\
\hline
\end{tabular}


at the neuromuscular junction. It also seems to affect the afferent arm of reflex bladder contractions. ${ }^{13,35,36}$

BONT-A is marketed under different brand names: Botox (onabotulinumtoxinA, Allergan, Irvine, CA), Dysport (abobotulinumtoxinA, Ipsen, Slough, Berkshire, UK), Xeomin (incobotulinumtoxinA, Merz Pharmaceuticals UK Ltd., Herts, UK), Prosigne (Lanzhou Biologic Products, Lanzhou, China) and PurTox (Mentor Corporation, Madison, WI). A direct comparison between these preparations in urology is not currently possible. Prosigne administration has been described in 1 study, ${ }^{37}$ but no studies have reported on Xeomin or PurTox for urological purposes. Recently, Xeomin (pure NTX-A) was shown to be inferior to Botox in cervical dystonia patients. ${ }^{36}$

As BONT-A therapy might be continued over many years, loss of therapeutic response has been reported in some patients. ${ }^{38}$ The loss of efficacy is due to the development of detectable neutralizing antibodies in these patients. ${ }^{39}$ Various factors might affect BONT-A immunogenicity. They include product-related factors, such as manufacturing process and antigenic protein load (accessory proteins have been shown to increase the immunological response to NTX-A ${ }^{40-42}$ ), as well as treatment-related factors, such as overall toxin dose and prior vaccination or exposure.

Detection of antibodies by laboratory tests might not necessarily predict the clinical success or failure of treatment. ${ }^{38}$ Chinnapongse and colleagues ${ }^{43}$ analyzed 4 prospective multicentre trials combining a total of 1134 subjects given BONT-B about every 3 months for cervical dystonia. The presence of antibodies to BONT-B, assessed by mouse-neutralizing antibody assay, did not have a meaningful clinical impact or correlate with treatment failure over total treatment durations of at least 6 years. No such studies have been conducted with BONT-A for urological indications.

The use of BONT-A in MS was extrapolated from initial studies on intradetrusor and intrasphincteric injection in $\mathrm{SCl}$ patients. ${ }^{44,45}$ OnabotulinumtoxinA (Botox) is currently approved in the United States, Canada and some European countries (France, Spain, Belgium, Germany, Poland, the Netherlands, but not yet in the UK, Italy and Switzerland) as a $200-U$ dose for intravesical injection in patients with urinary incontinence (UI) due to neurogenic detrusor overactivity (NDO), including MS patients. ${ }^{46}$ To date, BONT-A has not been approved to treat DESD.

\section{BONT-A in DO}

The procedure is often performed in outpatient settings, with a rigid or flexible cystoscope, after local anesthesia with intraurethral $2 \%$ lidocaine jelly, or $30 \mathrm{~mL}$ of intravesical $2 \%$ lidocaine for 10 minutes in poorly-tolerating subjects.

Multiple, disposable, flexible injection needles are available on the market. However, a 4-mm needle (BONEE,
Coloplast, Sweden) seems to have simplified the procedure. Although most initial studies delivered OnabotulinumtoxinA at the 300-U dose level, $200 \cup$ has been shown to be as effective in relieving symptoms and restoring continence; ${ }^{47-50}$ it is now the approved dosage. Recently, a small study reported significant improvement with $100 \cup .{ }^{51}$ AbobotulinumtoxinA is usually injected at a dose level of $500 \cup .^{52,53}$ It is diluted in saline 10 or $20 \mathrm{U} / \mathrm{mL}$, and $10 \mathrm{U}$ are injected per detrusor site. ${ }^{54-56}$ Injections are evenly distributed across the dome, posterior, right and left lateral walls of the bladder. Several reports have advocated the safety of trigone injection without vesicoureteral reflux. ${ }^{57,58}$ Smith and Chancellor ${ }^{59}$ suggested that $100 \mathrm{U}$ of onabotulinumtoxinA, diluted in $10 \mathrm{~mL}$ of preservative-free saline, can be injected submucosally into 10 trigone sites as effectively as 30 injection plans. Others have indicated that trigonal injections may improve daily incontinence and lead to better continence rates than detrusor injections alone; ${ }^{60-64}$ however, the urodynamic parameters in these studies were less affected.

\section{BONT-A in DESD}

EUS injections can be given alone or in combination with detrusor injections. OnabotulinumtoxinA (100 U) reconstituted in $4 \mathrm{~mL}$ of normal saline ${ }^{65}$ or AbobotulinumtoxinA $(150-250 \cup)^{66,67}$ can be administered. For cystoscopy-guided injection, the needle is inserted to a depth of $1 \mathrm{~cm}$ at 2 to 4 sites (12, 3, 6 and/or 9 o'clock) in the sphincter. ${ }^{67}$ Injection can also be delivered transperineally in men and transvaginally in women under electromyographic guidance at a single median site or as 2 paramedian injections. Recognition of EUS location is ensured through its activity during the bulbocavernous reflex. Both techniques can be performed under local anesthesia and are reported to be equally effective.

\section{Efficacy}

Few studies have specifically focused on MS patients, and most available data come from trials that included both $\mathrm{MS}$ and $\mathrm{SCl}$ patients (Table 2). Intradetrusor injection of BONT-A for DO management significantly reduces the number of urgency and UUI episodes and improves cystometric parameters (maximum cystometric capacity, maximum detrusor pressure during first involuntary detrusor contraction, maximum volume at first involuntary detrusor contraction) and health-related quality of life scores. BONT-A may also decrease urethral leakage in the setting of indwelling urinary catheters, ${ }^{76}$ and has been shown to reduce UTI frequency. ${ }^{71} \mathrm{MS}$ duration seems to be a predictive factor of BONT-A treatment failure, as neurological and urinary conditions worsen with time and result in more severe DO than in the early stage of the disease. ${ }^{68}$

Gallien and colleagues ${ }^{65}$ reported significantly increased voiding volume $(+54 \%, p=0.02)$ and reduction of pre- 
Table 2. Efficacy of BONT-A in voiding dysfunction secondary to MS

\begin{tabular}{llllcl}
\hline Author & $\begin{array}{c}\text { No. patients } \\
\text { with MS } \\
\text { (total no. } \\
\text { patients) }\end{array}$ & BONT-A type & Dosage & $\begin{array}{c}\text { Injection } \\
\text { site }\end{array}$ & $\begin{array}{c}\text { Urodynamic and/or QoL } \\
\text { outcomes }\end{array}$ \\
\hline
\end{tabular}

Cruz et al. ${ }^{47} \quad 154(275) \quad$ OnabotulinumtoxinA 200

$300 \mathrm{U}$

Ginsberg et al. ${ }^{48}$

$227(416)$

OnabotulinumtoxinA

200 or

$300 \mathrm{U}$

Deffontaines-

Rufin et al. ${ }^{68}$

$77(77)$

$300 U$

Khan et al. ${ }^{69}$

137 (137)

OnabotulinumtoxinA

$300 \mathrm{U}$

Herschorn et al. ${ }^{70}$

$19(57)$

OnabotulinumtoxinA

$300 \mathrm{U}$

Game et al. ${ }^{71}$

$15(30)$

OnabotulinumtoxinA

$300 \mathrm{U}$

Kalsi et al. ${ }^{72}$
Schurch et

OnabotulinumtoxinA

$300 \mathrm{U}$

al. $^{73}$

6 (59)

OnabotulinumtoxinA

200 or

$300 \mathrm{U}$

Schulte-

Baukloh et

$16(16)$

OnabotulinumtoxinA

$300 \mathrm{U}$

al. ${ }^{62}$

Ehren et al. ${ }^{74}$

6 (31)

AbobotulinumtoxinA

$500 \mathrm{U}$

Gallien et

al. ${ }^{65}$

86 (86)

OnabotulinumtoxinA

$100 \mathrm{U}$

100 or

$200 \mathrm{U}$

Smith et al. ${ }^{75}$

48 (110)

OnabotulinumtoxinA
Detrusor

$$
\text { MCC: }+60 \mathrm{~mL}
$$

Complete continence: $10.7 \%$ of patients

Improvement of I-QoL total scores

Detrusor

MCC: $+150 \mathrm{~mL}$

$P_{\text {detmaxIDC: }}:-25 \mathrm{cmH}_{2} \mathrm{O}$

MCC: $+300 \%$

Detrusor

Frequency: $-45 \%$

Incontinence episodes: $-77 \%$

Detrusor

Mean MCC: $+100 \mathrm{cc}$

Mean $\mathrm{P}_{\text {detmaxiDC }}$ : $-20 \mathrm{cmH}_{2} \mathrm{O}$

VV: $+54 \%$

UI: -24.2 (18.9) episodes/week

(117.5) mL . $+217.3(213.5) \mathrm{mL}$ $\mathrm{P}_{\text {(atmac }}:-28.4$ (31.9) $\mathrm{cmH}_{2} \mathrm{O}$

\section{UUI: -1.1 episodes/day}

MCC: $+58 \%-77 \%$

Pad use: $-38 \%-64 \%$

$$
\begin{aligned}
& P_{\text {detmaxiIDC: }}-21 \% \\
& \text { MUCP: }-21 \%
\end{aligned}
$$

\section{EUS (32}

patients)

Detrusor

(16 Improvement of PVR, $\mathrm{P}_{\text {detmaxIDC' }}$
MCC
UI: -23 episodes/week

100 or $300 \mathrm{U}$

Multicentre, international, randomized, double-blind, placebo-controlled phase 3 study

52-week, multicentre international, randomized, double-blind, placebocontrolled trial

Trigone-sparing injections

Mean follow-up 29

months (9-80)

Results at 36 months in both groups ( $\mathrm{SCl}$ and $\mathrm{MS}$ )

Decrease in incidence of symptomatic urinary infections

No stratification of results by NDO etiology Intake of antimuscarinics significantly lower in BONT-A group

Included trigonal injections

QoL: quality of life; BONT-A: botulinum neurotoxin-A; MS: multiple sclerosis; DC: detrusor compliance; EUS: external urethral sphincter; IIQ-7: Incontinence Impact Questionnaire-short form; I-QoL: incontinence QoL; MCC: maximum cystometric capacity; MUCP: maximal urethal closure pressure; NDO: neurogenic detrusor overactivity; PdetmaxIDC: maximum detrusor pressure during first involuntary detrusor contraction; SD: standard deviation; UDI-6: Urogenital Distress Inventory questionnaire-short form; UI: urinary incontinence; UUI: urinary urge incontinence; VpmaxIDC: volume at first IDC; VN: volume/void (volume per void is derived from total voided volume over a 24-hour period). 
micturition and maximal detrusor pressures with EUS injection compared to placebo $(-29 \%$ and $-21 \%$, respectively, $p=0.02$ ), with similar tolerance. However, they noted improvement of PVR.

In general, BONT-A efficacy is limited in duration. Previous studies suggest that benefits begin to wane after 6 months $^{34}$ with intradetrusor injection. Ginsberg and colleagues ${ }^{48}$ report a median time of 8.4 months to patient re-treatment request. When injected in the EUS, efficacy is maintained for 1 to 4 months. ${ }^{67,68}$ Repeat BONT-A injections remain effective in most patients. ${ }^{63,71}$

\section{Safety}

Bladder or urethral BONT-A injection is generally administered under local anesthesia and is well-tolerated. The most common adverse effects are bladder pain, UTI (2\%$35 \%)$, urinary retention $(17 \%-20 \%)$ and mild hematuria (2\%-20\%). ${ }^{47,48}$ Patients should be consulted about the risk of de novo CIC because of increased PVR $(30 \%-40 \%$ of patients) ${ }^{47}$ No severe systemic effects directly related to BONT-A injection have been reported to date, although a few patients experience benign, transient generalized weakness after treatment. ${ }^{77}$

Data on the risk of UTI after Botox injection are conflicting. Some authors report reduced risk, ${ }^{65}$ while others report an increased risk of UTI. ${ }^{77}$

\section{Current BONT-A treatment in MS}

Intradetrusor BONT-A injection is now an approved treatment modality for UI secondary to NDO. It should be available to patients who failed first-line therapy (behavioural modifications and oral therapy), before considering more invasive alternatives (e.g., sacral neuromodulation). ${ }^{29} \mathrm{Few}$ studies have compared BONT-A to other intravesical vanilloids (capsaicin, resiniferatoxin) whose efficacy is supported by level $1 \mathrm{~b}$ evidence. ${ }^{78,79}$ One randomized investigation compared BONT-A to resiniferatoxin as second-line therapy of NDO patients. ${ }^{80}$ BONT-A significantly decreased the frequency of daily incontinence episodes $(p<0.05)$, significantly increased first uninhibited detrusor contractions $(p<0.01)$ and maximum bladder capacity $(p<0.01)$, and significantly reduced maximum pressure of uninhibited detrusor contractions $(p<0.01)$ compared to resiniferatoxin at the 6-, 12- and 18-month follow-up. However, this study investigated only $\mathrm{SCl}$ patients. There is level 1 evidence of BONT-A efficacy and safety in DESD, but its application remains off-label.

\section{Conclusion}

The progressive nature of MS, which results in significant disability along with extensive shifting of urodynamic parameters, makes patients different from those with idiopathic and neurogenic DO. In this setting, BONT-A exerts significantly beneficial qualitative and quantitative effects in patients who are refractory to first-line therapy, with good levels of evidence. Intradetrusor and intrasphincteric injections are well-tolerated, with minimal risk of systemic adverse events.

Competing interests: Dr. Adli declares no competing financial or personal interests. Dr. Corcos has been a paid consultant for Allergan, Astellas and Actavis.

This paper has been peer-reviewed.

\section{References}

1. Houtchens MK, Lublin FD, Miller AE, et al. Multiple sclerosis and other inflammatory demyelinating diseases of the central nervous system. Bradley's Neurology in Clinical Practice, 6th edition, Philadelphia, PA: Elsevier; 2012:1283-313. http://dx.doi.org/10.1016/B978-1-4377-0434-1.00079-7

2. Noseworthy JH, Lucchinetti C, Rodriguez M, et al. Multiple sclerosis. N Engl J Med 2000;343:938-52. http://dx.doi.org/10.1056/NEJM200009283431307

3. Polman CH, Reingold SC, Edan G, et al. Diagnostic criteria for multiple sclerosis: 2005 revisions to the "McDonald Criteria." Ann Neurol 2005;58:840-6. http://dx.doi.org/10.1002/ana.20703

4. Betts $C D, D^{\prime}$ Mellow MT, Fowler $C J$. Urinary symptoms and the neurological features of bladder dysfunction in multiple sclerosis. J Neurol Neurosurg Psychiatry 1993;56:245-50. http://dx.doi.org/10.1136/ jnnp.56.3.245

5. Bradley WE. Urinary bladder dysfunction in multiple sclerosis. Neurology 1978;28:52-8. http://dx.doi. org/10.1212/WNL.28.9_Part_2.52

6. Mahajan ST, Patel PB, Marrie RA. Under treatment of overactive bladder symptoms in patients with multiple sclerosis: An ancillary analysis of the NARCOMS Patient Registry. J Urol 2010;183:1432-7. http://dx.doi.org/10.1016/i.juro.2009.12.029

7. Athwal BS, Berkley KJ, Hussain I, et al. Brain responses to changes in bladder volume and urge to void in healthy men. Brain 2001;124:369-77. http://dx.doi.org/10.1093/brain/124.2.369

8. Blok BF, Willemsen AT, Holstege G. A PET study on brain control of micturition in humans. Brain 1997;120:111-21. http://dx.doi.org/10.1093/brain/120.1.111

9. Blok BF. Central pathways controlling micturition and urinary continence. Urology 2002;59(5 Suppl 1):13-7. http://dx.doi.org/10.1016/50090-4295(01)01633-8

10. Di Benedetto P, Delneri C, Biasutti E, et al. Vesicourethral dysfunction in multiple sclerosis. Initial assessment based on lower urinary tract symptoms and their pathophysiology. Neurol Sci 2008;29:S348-51. http://dx.doi.org/10.1007/s10072-008-1041-z

11. Awad SA, Gajewski JB, Sogbein SK, et al. Relationship between neurological and urological status in patients with multiple sclerosis. J Urol 1984;132:499-502.

12. Koldewijn EL, Hommes $\mathrm{OR}$, Lemmens WA, et al. Relationship between lower urinary tract abnormalities and disease-related parameters in multiple sclerosis. J Urol 1995;154:169-73. http://dx.doi.org/10.1016/ S0022-5347(01)67258-6

13. Kalsi V, Fowler CJ. Therapy insight: Bladder dysfunction associated with multiple sclerosis. Nat Clin Pract Urol 2005;2:492-501. http://dx.doi.org/10.1038/ncpuro0323

14. Buchanan RJ, Martin RA, Wang $S$, et al. Analyses of nursing home residents with multiple sclerosis at admission and one year after admission. Mult Scler 2004;10:74-9. http://dx.doi. org/10.1191/1352458504ms9690a

15. Nijeholt GJ, van Walderveen MA, Castelijns JA, et al. Brain and spinal cord abnormalities in multiple sclerosis. Correlation between MRI parameters, clinical subtypes and symptoms. Brain 1998;121:687-97. http://dx.doi.org/10.1093/brain/121.4.687 
16. Ukkonen $M$, Elovaara I, Dastidar $\mathrm{P}$, et al. Urodynamic findings in primary progressive multiple sclerosis are associated with increased volumes of plaques and atrophy in the central nervous system. Acta Neurol Scand 2004;109:100-5. http://dx.doi.org/10.1034/i.1600-0404.2003.00184.x

17. Araki I, Matsui M, Ozawa K, et al. Relationship of bladder dysfunction to lesion site in multiple sclerosis. J Urol 2003;169:1384-7. http://dx.doi.org/10.1097/01.ju.0000049644.27713.c8

18. Leruitte A, Ketelaer $P$, Vereecken R. Micturitional disorders in multiple sclerosis. Urol Int 1976;31:230-8. http://dx.doi.org/10.1159/000280056

19. Kim YH, Goodman C, Omessi E, et al. The correlation of urodynamic findings with cranial magnetic resonance imaging findings in multiple sclerosis. J Urol 1998;159:972-6. http://dx.doi.org/10.1016/ S0022-5347(01)63791-1

20. Mayo ME, Chetner MP. Lower urinary tract dysfunction in multiple sclerosis. Urology 1992;39:67-70. http://dx.doi.org/10.1016/0090-4295(92)90045-X

21. Amarenco $G$, Kerdraon J, Denys P. Bladder and sphincter disorders in multiple sclerosis. Clinical, urodynamic and neurophysiological study of 225 cases. Rev Neurol (Paris) 1995;151:722-30.

22. Giannantoni A, Scivoletto G, Di Stasi SM, et al. Urological dysfunctions and upper urinary tract involvement in multiple sclerosis patients. Neurourol Urodyn 1998;17:89-98. http://dx.doi.org/10.1002/ (SICI) 1520-6777(1998) 17:2<89::AID-NAU2>3.0.C0;2-8

23. Gallien $P$, Robineau $S$, Nicolas $B$, et al. Vesicourethral dysfunction and urodynamic findings in multiple sclerosis: A study of 149 cases. Arch Phys Med Rehabil 1998;79:255-7. http://dx.doi.org/10.1016/ S0003-9993(98)90003-X

24. Hennessey A, Robertson NP, Swingler R, et al. Urinary, faecal and sexual dysfunction in patients with multiple sclerosis. J Neurol 1999;246:1027-32. http://dx.doi.org/10.1007/s004150050508

25. de Sèze $M$, Ruffion A, Denys $P$, et al.; and GENULF. The neurogenic bladder in multiple sclerosis: Review of the literature and proposal of management guidelines. Mult Scler 2007;13:915-28. http://dx.doi. org/10.1177/1352458506075651

26. Bart S, De Sèze $M$, Chartier-Kastler E, et al. Lower urinary tract dysfunction and multiple sclerosis. Prog Urol 2007;17:358-64. http://dx.doi.org/10.1016/S1166-7087(07)92330-1

27. Lemack GE, Frohman EM, Zimmern PE, et al. Urodynamic distinctions between idiopathic detrusor overactivity and detrusor overactivity secondary to multiple sclerosis. Urology 2006;67:960-4. http://dx.doi. org/10.1016/i.urology.2005.11.061

28. Ciancio SJ, Mutchnik SE, Rivera VM, et al. Urodynamic pattern changes in multiple sclerosis. Urology 2001;57:239-45. htrp://dx.doi.org/10.1016/S0090-4295(00)01070-0

29. Fowler $\mathrm{CJ}$, Panicker JN, Drake M, et al. A UK consensus on the management of the bladder in multiple sclerosis. J Neurol Neurosurg Psychiatry 2009:80:470-7.

30. Nicholas RS, Friede T, Hollis S, Young CA. Anticholinergics for urinary symptoms in multiple sclerosis. Cochrane Database of Systematic Reviews 2009:1:CD004193.

31. Nicholas R, Young C, Fried T. Bladder symptoms in multiple sclerosis: a review of pathophysiology and management. Expert Opin Drug Saf 2010;9:905-15. http://dx.doi.org/10.1517/14740338.201 0.501793

32. Fowler CJ. Systematic review of therapy for neurogenic detrusor overactivity. Can Urol Assoc J 2011;5:S146-8. http://dx.doi.org/10.5489/cuaj.11187

33. MacDonald R, Monga M, Fink HA, et al. Neurotoxin treatments for urinary incontinence in subjects with spinal cord injury or multiple sclerosis: A systematic review of effectiveness and adverse effects. J Spinal Cord Med 2008:31:157-65.

34. Stoffel JT. Contemporary management of the neurogenic bladder for multiple sclerosis patients. Urol Clin North Am 2010;37:547-57. http://dx.doi.org/10.1016/i.ucl.2010.06.003

35. Khera $M$, Somogyi GT, Kiss $S$, et al. Botulinum toxin A inhibits ATP release from bladder urothelium after chronic spinal cord injury. Neurochem Int 2004;45:987-93. http://dx.doi.org/10.1016/i neuint.2004.06.001

36. Yokoyama T, Chancellor MB, Oguma K, et al. Botulinum toxin type A for the treatment of lower urinary tract disorders. Int J Urol 2012;19:202-15. http://dx.doi.org/10.1111/i.1442-2042.2011.02946.x

37. Gomes CM, Castro Filho JE, Rejowski RF, et al. Experience with different botulinum toxins for the treatment of refractory neurogenic detrusor overactivity. Int Braz J Urol 2010;36:66-74. http://dx.doi. org/10.1590/S1677-55382010000100011

38. Naumann M, Boo LM, Ackerman AH, et al. Immunogenicity of botulinum toxins. J Neural Transm 2013;120:275-90. http://dx.doi.org/10.1007/s00702-012-0893-9. Epub 2012 Sep 25

39. Dressler $D$. Clinical presentation and management of antibody-induced failure of botulinum toxin therapy. Mov Disord 2004;19:592-100. http://dx.doi.org/10.1002/mds.20022

40. Benecke R. Clinical relevance of botulinum toxin immunogenicity. BioDrugs 2012;26:el-9. http://dx.doi. org/10.2165/11599840-000000000-00000

41. Lee JC, Yokota K, Arimitsu H, et al. Production of anti-neurotoxin antibody is enhanced by two subcomponents, HAl and HA3b, of Clostridium botulinum type B 16S toxin-haemagglutinin. Microbiology 2005;151 (Pt 11):3739-47. http://dx.doi.org/10.1099/mic.0.28421-0
42. Kukreja R, Chang T-W, Cai S, et al. Immunological characterization of the subunits of type A botulinum neurotoxin and different components of its associated proteins. Toxicon 2009;53:616-24. http://dx.doi. org/10.1016/i.toxicon.2009.01.017

43. Chinnapongse RB, Lew MF, Ferreira JJ, et al. Immunogenicity and long-term efficacy of botulinum toxin type B in the treatment of cervical dystonia: Report of 4 prospective, multicenter trials. Clin Neuropharmacol 2012;35:215-23. http://dx.doi.org/10.1097/WNF.0b013e318263163c

44. Schurch B, Stöhrer M, Kramer G, et al. Botulinum-A toxin for treating detrusor hyperreflexia in spinal cord injured patients: A new alternative to anticholinergic drugs? Preliminary results. J Urol 2000;164:692-7.

45. Dykstra DD, Sidi AA. Treatment of detrusor-sphincter dyssynergia with botulinum A toxin: A double-blind study. Arch Phys Med Rehabil 1990;71:24-6.

46. Botox@ [Prescribing information]. Irvine, CA: Allergan Pharmaceuticals, Inc., August; 2011.

47. Cruz $F$, Herschorn $S$, Aliotta $P$, et al. Efficacy and safety of onabotulinumtoxinA in patients with urinary incontinence due to neurogenic detrusor overactivity: A randomised, double-blind, placebo-controlled trial. Eur Urol 2011;60:742-50. http://dx.doi.org/10.1016/i.eururo.2011.07.002

48. Ginsberg D, Gousse A, Keppenne V, et al. Phase 3 efficacy and tolerability study of onabotulinumtoxinA for urinary incontinence from neurogenic detrusor overactivity. J Urol 2012;187:2131-9. http://dx.doi. org/10.1016/i.juro.2012.01.125

49. Chancellor MB, Patel V, Leng $W$, et al. OnabotulinumtoxinA in patients with urinary incontinence due to neurogenic detrusor overactivity: Effects on health related quality of life. Urological Association Annual Meeting, May 2011, Abstract 1518.

50. Mangera A, Andersson KE, Apostolidis A, et al. Contemporary management of lower urinary tract disease with botulinum toxin A: A systematic review of botox (onabotulinumtoxinA) and dysport (abobotulinumtoxinA). Eur Urol 2011;60:784-95. http://dx.doi.org/10.1016/.eururo.2011.07.001. Epub 2011 Jul 13.

51. Mehnert U, Birzele J, Reuter $\mathrm{K}$, et al. The effect of botulinum toxin type a on overactive bladder symptoms in patients with multiple sclerosis: A pilot study. J Urol 2010;184:1011-6. http://dx.doi.org/10.1016/i. juro.2010.05.035

52. Ehren I, Volz D, Farrelly E, et al. Efficacy and impact of botulinum toxin A on quality of life in patients with neurogenic detrusor overactivity: A randomised, placebo-controlled, double-blind study. Scand I Urol Nephrol 2007;41:335-40. http://dx.doi.org/10.1080/00365590601068835

53. Grise $P$, Ruffion $A$, Denys $P$, et al. Efficacy and tolerability of botulinum toxin type $A$ in patients with neurogenic detrusor overactivity and without concomitant anticholinergic therapy: Comparison of two doses. Eur Urol 2010;58:759-66. http://dx.doi.org/10.1016/i.eururo.2010.06.035

54. Apostolidis A, Dasgupta $P$, Denys $P$, et al.; European Consensus Panel. Recommendations on the use of botulinum toxin in the treatment of lower urinary tract disorders and pelvic floor dysfunctions: A European consensus report. Eur Urol 2009;55:100-19. http://dx.doi.org/10.1016/j.eururo.2008.09.009

55. Dasgupta P. Volume matters: bladder injections of botulinum toxin type a. Eur Urol 2012;61:1185-6. http://dx.doi.org/10.1016/j.eururo.2012.02.043

56. Sahai A, Kalsi V, Khan MS, et al. Techniques for the intradetrusor administration of botulinum toxin. BJU Int 2006;97:675-8. http://dx.doi.org/10.1111/i.1464-410X.2006.06063.x

57. Karsenty $G$, Elzayat E, Delapparent $T$, et al. Botulinum toxin type a injections into the trigone to treat idiopathic overactive bladder do not induce vesicoureteral reflux. J Urol 2007;177:1011-4. http:// dx.doi.org/10.1016/i.juro.2006.10.047

58. Manecksha RP, Cullen IM, Sarfraz A, et al. Prospective randomised controlled trial comparing trigonesparing versus trigone-including intradetrusor injection of abobotulinumtoxinA for refractory idiopathic detrusor overactivity. Eur Urol 2012;61:928-35. http://dx.doi.org/10.1016/i.eururo.2011.10.043

59. Smith CP, Chancellor MB. Simplified bladder botulinum-toxin delivery technique using flexible cystoscope and 10 sites of injection. J Endourol 2005;19:880-2. http://dx.doi.org/10.1089/end.2005.19.880

60. Chapple CR. Which preparation of botulinum toxin a should be used, where should it be injected, and how should its efficacy be assessed? Eur Urol 2012;61:936-7. http://dx.doi.org/10.1016/j. eururo.2011.12.005

61. Kuo HC. Comparison of effectiveness of detrusor, suburothelial and bladder base injections of botulinum toxin a for idiopathic detrusor overactivity. J Urol 2007;178:1359-63. http://dx.doi.org/10.1016/i. juro.2007.05.136

62. Schulte-Baukloh H, Schobert J, Stolze T, et al. Efficacy of botulinum-A toxin bladder injections for the treatment of neurogenic detrusor overactivity in multiple sclerosis patients: An objective and subjective analysis. Neurourol Urodyn 2006;25:110-5. http://dx.doi.org/10.1002/nau.20153

63. Ghalayini IF, Al-Ghazo MA, Elnasser ZA. Is efficacy of repeated intradetrusor botulinum toxin type A (Dysport) injections dose dependent? Clinical and urodynamic results after four injections in patients with drug-resistant neurogenic detrusor overactivity. Int Urol Nephrol 2009;41:805-13. http://dx.doi. org/10.1007/s1 1255-009-9528-y

64. Abdel-Meguid TA. Botulinum toxin-A injections into neurogenic overactive bladder-to include or exclude the trigone? A prospective, randomized, controlled trial. J Urol 2010;184:2423-8. http://dx.doi. org/10.1016/i.juro.2010.08.028 
65. Gallien P, Reymann JM, Amarenco G, et al. Placebo controlled, randomised, double blind study of the effects of botulinum A toxin on detrusor sphincter dyssynergia in multiple sclerosis patients. J Neurol Neurosurg Psychiatry 2005;76:1670-6. http://dx.doi.org/10.1136/innp.2004.045765

66. Petit $H$, Wiart L, Gaujard $E$, et al. Botulinum A toxin treatment for detrusor-sphincter dyssynergia in spinal cord disease. Spinal Cord 1998;36:91-4. http://dx.doi.org/10.1038/si.sc.3100517

67. Mahfouz W, Corcos J. Management of detrusor external sphincter dyssynergia in neurogenic bladder. Eur J Phys Rehabil Med 2011;47:639-50.

68. Deffontaines-Rufin $S$, Weil $M$, Verollet D, et al. Botulinum toxin A for the treatment of neurogenic detrusor overactivity in multiple sclerosis patients. Int Braz J Urol 2011;37:642-8. http://dx.doi.org/10.1590/ S1677-55382011000500012

69. Khan S, Game X, Kalsi V, et al. Long-term effect on quality of life of repeat detrusor injections of botulinum neurotoxin-A for detrusor overactivity in patients with multiple sclerosis. J Urol 2011;185:1344-9. http:// dx.doi.org/10.1016/i.juro.2010.12.002

70. Herschorn S, Gajewski J, Ethans K, et al. Efficacy of botulinum toxin A injection for neurogenic detrusor overactivity and urinary incontinence: a randomized, double-blind trial. J Urol 2011;185:2229-35. http:// dx.doi.org/10.1016/i.juro.2011.02.004

71. Gamé X, Caste-Lacanal E, Bentaleb Y, et al. Botulinum toxin A detrusor injections in patients with neurogenic detrusor overactivity significantly decrease the incidence of symptomatic urinary tract infections. Eur Urol 2008;53:613-8. http://dx.doi.org/10.1016/j.eururo.2007.08.039

72. Kalsi $V$, Gonzales $G$, Popat $R$, et al. Botulinum injections for the treatment of bladder symptoms of multiple sclerosis. Ann Neurol 2007;62:452-7. http://dx.doi.org/10.1002/ana.21209

73. Schurch B, Denys $P$, Kozma $C M$, et al. Botulinum toxin A improves the quality of life of patients with neurogenic urinary incontinence. Eur Urol 2007;52:850-8. http://dx.doi.org/10.1016/j.eururo.2007.04.026
74. Ehren I, Volz D, Farrelly E, et al. Efficacy and impact of botulinum toxin A on quality of life in patients with neurogenic detrusor overactivity: A randomised, placebo-controlled, double-blind study. Scand I Urol Nephrol 2007;41:335-40. http://dx.doi.org/10.1080/00365590601068835

75. Smith $C P$, Nishiguchi J, $O^{\prime}$ Leary $M$, et al. Single-institution experience in 110 patients with botulinum toxin A injection into bladder or urethra. Urology 2005;65:37-41. http://dx.doi.org/10.1016/i.urotogy.2004.08.016

76. Lekka E, Lee LK. Successful treatment with intradetrusor Botulinum-A toxin for urethral urinary leakage (catheter bypassing) in patients with end-staged multiple sclerosis and indwelling suprapubic catheters. Eur Urol 2006;50:806-9. http://dx.doi.org/10.1016/i.eururo.2005.12.015

77. Del Popolo G, Filocamo MT, Li Marzi V, et al. Neurogenic detrusor overactivity treated with english botulinum toxin a: 8-year experience of one single centre. Eur Urol 2008;53:1013-9. http://dx.doi. org/10.1016/i.eururo.2007.09.034

78. de Sèze M, Wiart L, Joseph PA, et al. Capsaicin and neurogenic detrusor hyperreflexia: A double-blind placebo-controlled study in 20 patients with spinal cord lesions. Neurourol Urodyn 1998;17:513-23. http://dx.doi.org/10.1002/(SICI) 1520-6777(1998) 17:5<513::AlD-NAU7>3.0.C0;2-G

79. Kim JH, Rivas DA, Shenot PJ, et al. Intravesical resiniferatoxin for refractory detrusor hyperreflexia: A multicenter, blinded, randomized, placebo-controlled trial. J Spinal Cord Med 2003;26:358-63.

80. Giannantoni A, Di Stasi SM, Stephen RL, et al. Intravesical resiniferatoxin versus botulinum-A toxin injections for neurogenic detrusor overactivity: A prospective randomized study. J Urol 2004;172:240-3. http:// dx.doi.org/10.1097/01.ju.0000132152.53532.5d

Correspondence: Dr. Jacques Corcos, Department of Urology, Jewish General Hospital, 3755 CôteSainte-Catherine Road, Montreal, QC H3T 1E2; jcorcos@uro.jgh.mcgill.ca 